\begin{tabular}{|c|l|}
\hline Title & An A ntiviral Agent (46NW-04A) Produced by Pseudomonas sp. and Its A ctivity ageinst Fish V iruses \\
\hline Author(s) & Kimura, Takahisa; Y oshimizu, Mamoru; Ezura, Y oshio; Kamei, Y uto \\
\hline Citation & $\begin{array}{l}\text { Journal of A quatic A nimal Health, 2(1), 12-20 } \\
\text { https://doi.org/10.1577/1548-8667(1990)002<0012:A A A PBP >2.3.C0;2 }\end{array}$ \\
\hline Issue Date & 1990-01 \\
\hline Doc URL & http://hdl.handle.net/2115/38309 \\
\hline Type & article \\
\hline File Information & yoshimizu-81.pdf \\
\hline
\end{tabular}

Instructions for use 


\title{
An Antiviral Agent (46NW-04A) Produced by Pseudomonas sp. and Its Activity against Fish Viruses
}

\author{
Takahisa Kimura, Mamoru Yoshimizu, Yoshio Ezura, and Yuto Kamei \\ Laboratory for Microbiology, Faculty of Fisheries \\ Hokkaido University, Hakodate 041, Japan
}

\begin{abstract}
The antiviral agent 46NW-04A was isolated and characterized from cell-free culture fluid of Pseudomonas sp. 46NW-04 isolated from the aquatic environment. Production of the antiviral substance was maximal at $25^{\circ} \mathrm{C}$ during days $2-3$ of bacterial incubation. Extraction from $30 \mathrm{~L}$ of culture fluid by ethyl acetate and purification by thin-layer chromatography on silica gel resulted in $709 \mathrm{mg}$ of the purified antiviral material. Molecular weight of this substance was 1,126 by secondary ionization mass spectrometry, and chemical properties suggested that $46 \mathrm{NW}-04 \mathrm{~A}$ was a peptide. Its antiviral activity, measured as the concentration causing $100 \%$ plaque reduction, was $25 \mu \mathrm{g} / \mathrm{mL}$ against Oncorhynchus masou virus and infectious hematopoietic necrosis virus. However, no antiviral activity was observed against infectious pancreatic necrosis virus at the concentrations tested. Pseudomonas sp. 46NW-04 was identified as Pseudomonas fluorescens biovar I.
\end{abstract}

The survival and interaction of viruses and other microorganisms in aquatic environments are important areas for study. Several reports have described the inactivation of viruses in natural water and activated sludges. This antiviral activity seemed to be related to microorganisms inherent in these environments (Magnusson et al. 1967; Fujioka et al. 1980; Toranzo et al. 1982, 1983; Ward 1982; Ward et al. 1986; Knowlton and Ward 1987). It has been reported that this inactivation was caused by proteolytic enzymes produced by bacteria (Cliver and Herrmann 1972; Toranzo et al. 1982, 1983; Ward et al. 1986; Knowlton and Ward 1987). These proteolytic enzymes were not characterized or isolated from the bacteria, although some properties were studied by heat treatment, dialysis, and release by solubilizing agents.

Previously, we investigated the antiviral activity of microorganisms in the hydrosphere (Kamei et al. 1987a, 1987b, 1988a 1988b). In a series of studies on the aquatic microbial ecosystem, we reported the inactivation of fish viruses by natural fresh, brackish, and seawaters. This inactivation appears to be principally caused by bacteria in the water (Kamei et al. 1987a, 1988a). A large number of bacteria were screened from the aquatic environments and some, such as species of Pseudomonas, Achromobacter, and Vibrio, were found to have antiviral properties (Kamei et al. 1987b, 1988b). Pseudomonas sp. 46NW-04 was isolated from the water of the Nanae Fish Culture Experimental Station of Hokkaido University in Hokkaido, Japan. This bacterium produces a sub- stance with potent antiviral activity, which was detected in culture fluid and is effective against infectious hematopoietic necrosis virus (IHNV; Kamei et al. 1988b).

In this study, we isolated and characterized the anti-IHNV agent 46NW-04A from supernatants of cultured Pseudomonas sp. 46NW-04. We also conducted a taxonomic comparison of Pseudomonas sp. $46 \mathrm{NW}-04$ with seven reference species of Pseudomonas by using Bergey's Manual of Systematic Bacteriology (Palleroni 1984).

\section{Methods}

Cell cultures. - Gonad cells from rainbow trout Oncorhynchus mykiss (RTG-2; Wolf and Quimby 1962) were used for propagation of viruses, and embryo cells from chinook salmon Oncorhynchus tshawytscha (CHSE-214; Fryer et al. 1965) were used for plaque assay. For the plaque assay, cells were grown at $15^{\circ} \mathrm{C}$ in MEM-10-tris medium composed of Eagle's minimum essential medium (MEM, GIBCO), 10\% fetal bovine serum (M.A. Bioproduct), $0.075 \% \mathrm{NaHCO}_{3}, 100$ international units penicillin/mL (Sigma), $100 \mu \mathrm{g}$ streptomycin/ $\mathrm{mL}$ (Sigma), and $1.6 \%$ tris buffer [tris(hydroxymethyl)aminomethane-(tris)hydrochloride] (Sigma) adjusted to $\mathrm{pH}$ 7.8. According to the method of Kamei et al. (1987c), the cells were suspended in growth medium and seeded in 24well plates (16-mm-diameter wells, Falcon) to give approximately $10^{6}$ cells $/ \mathrm{mL}$ in the wells. After 1 $\mathrm{d}$, the monolayers were used for the plaque assay.

Viruses. - The IHNV (strain ChAb) and Oncorhynchus masou virus (OMV; strain 00-7812) were 
Stock culture, Pseudomonas sp. 46W-04

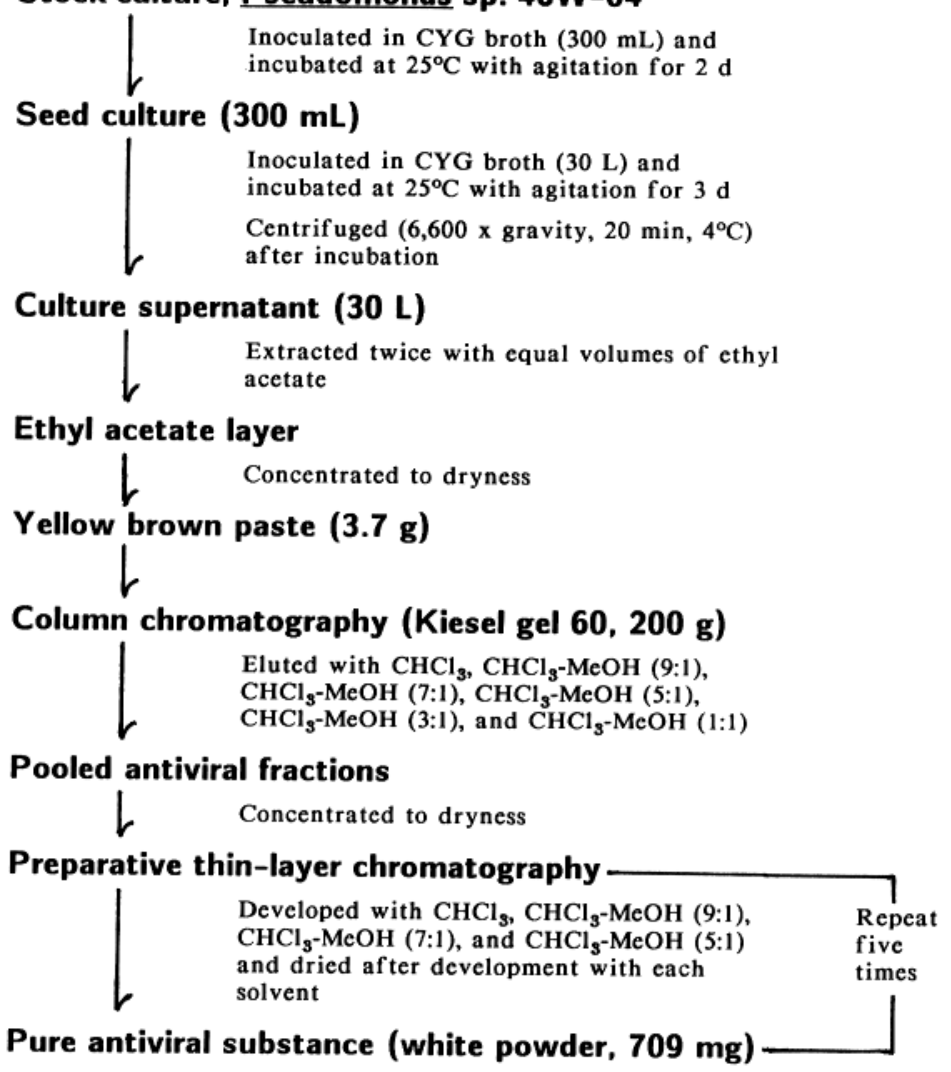

FIGURE 1.-Outline of procedure for isolation of antiviral substance $46 \mathrm{NW}-04 \mathrm{~A}$. CYG $=$ casamino acid-yeast extract-glucose broth.

isolated in our laboratory from chum salmon $\mathrm{On}$ corhynchus keta and masu salmon $O$. masou, respectively. Infectious pancreatic necrosis virus (IPNV; strain VR299) was provided by J. L. Fryer (Oregon State University). These stock viruses were propagated at $15^{\circ} \mathrm{C}$ with RTG-2 cells in 75$\mathrm{cm}^{2}$ tissue culture flasks (Falcon) containing 25 $\mathrm{mL}$ of MEM-10-tris medium. When the cytopathic effect was complete, the culture fluid was removed from the flasks and clarified by centrifugation at $2,100 \times$ gravity at $4^{\circ} \mathrm{C}$ for $20 \mathrm{~min}$. The supernatants were filtered through a $0.40-\mu \mathrm{m}$-pore filter (Nuclepore) for OMV and $0.45-\mu \mathrm{m}$-pore filter (Millex-HA, Millipore) for IHNV and IPNV. The titers of IHNV, IPNV, and OMV that yielded a tissue culture infective dose per milliliter causing a cytopathic effect in $50 \%$ of cultures inoculated (TCID50/mL) were $10^{5.8}, 10^{8.3}$, and $10^{4.3}$, respectively. The viruses were stored at $-80^{\circ} \mathrm{C}$ in $2.0-$ $\mathrm{mL}$ aliquots until used.

Plaque assay.-Production of antiviral substances by bacteria was ascertained by plaque-re- duction assay with IHNV (Kamei et al. 1987c, 1988b). Purified 46NW-04A was dissolved in dimethylsulfoxide (DMSO) and diluted with Hanks' balanced salt solution (Hanks' BSS, GIBCO) to make a stock solution of $1 \mathrm{mg} / \mathrm{mL}$. The stock solution was diluted to desired concentrations with Hanks' BSS containing 1\% DMSO. A 0.2-mL aliquot of the dilution was mixed with an equal volume of IHNV suspension containing approximately 150 plaque-forming units (PFU)/0.1 mL and incubated at $15^{\circ} \mathrm{C}$ for $1 \mathrm{~h}$. The control fluid was $1 \%$ DMSO in Hanks' BSS.

Determination of optimal conditions for $46 \mathrm{NW}$ $04 \mathrm{~A}$ production. - Determination of optimum incubation temperature for Pseudomonas sp. 46NW04 was done by inoculating a loopful of seed culture $\left(5.1 \times 10^{9}\right.$ colony-forming units $(\mathrm{CFU}) /$ $\mathrm{mL}$ ) into $15 \mathrm{~mL}$ of casamino acid-yeast extractglucose (CYG) broth (Kamei et al. 1988b) in L-form test tubes and incubating these with agitation at temperatures ranging from 10 to $33^{\circ} \mathrm{C}$ for $2 \mathrm{~d}$ with a Temperature Gradient Bio-photorecorder (TN- 


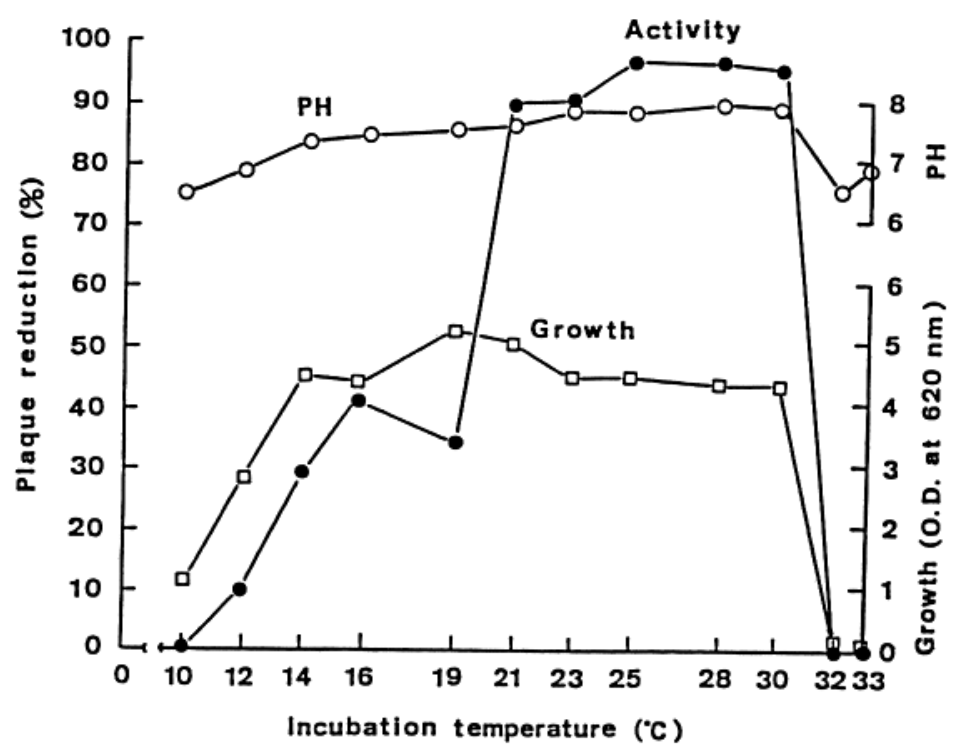

FIGURE 2.-Effect of incubation temperature on growth and production of anti-IHNV agent by Pseudomonas sp. 46NW-04; O.D. = optical density.

112D, Toyo Kagaku Sangyo Co., Ltd.). After incubation, the $\mathrm{pH}$ and optical density at $620 \mathrm{~nm}$ were measured, and the culture broth was tested for antiviral activity by plaque-reduction assay. For the determination of the rate of production of the antiviral substance, the bacterium was grown in $400 \mathrm{~mL}$ of CYG broth in a $500-\mathrm{mL}$ Sakaguchi flask and incubated with agitation at $25^{\circ} \mathrm{C}$ for $7 \mathrm{~d}$. At 12-h intervals, 5-mL aliquots of the culture were aseptically withdrawn, and the $\mathrm{pH}$ was measured. Antiviral activity then was determined by plaque reduction.

Isolation and purification of antiviral substance $46 N W-04 A$. - One loopful of stock culture of Pseudomonas sp. 46NW-04 was inoculated in 300 $\mathrm{mL}$ of CYG broth in a 500-mL Sakaguchi flask and incubated with agitation at 160 revolutions per minute for $2 \mathrm{~d}$ at $25^{\circ} \mathrm{C}$. Four 2.5-L CYG broths in Erlenmeyer flasks were each inoculated with 25 $\mathrm{mL}$ of broth culture and incubated with agitation at $25^{\circ} \mathrm{C}$ for $3 \mathrm{~d}$. After incubation, the spent culture was centrifuged at $6,600 \times$ gravity at $4^{\circ} \mathrm{C}$ for 20 min. The supernatant was extracted twice with an equal volume of ethyl acetate, and the ethyl acetate layer was concentrated to $2 \mathrm{~L}$ under vacuum at $25^{\circ} \mathrm{C}$. The concentrated solvent phase was dehydrated with $\mathrm{Na}_{2} \mathrm{SO}_{4}$ (anhydrous) and evaporated to dryness. This extraction was conducted three times to obtain extracts from $30 \mathrm{~L}$ of culture fluid (Figure 1). Detection of 46NW-04A was carried out with anisaldehyde reagent (Stahl and Kaltenbach 1961).
Chemical analysis. - Solubility of 46NW-04A in solvent was tested with acetone, benzene, chloroform, diethyl ether, DMSO, ethanol, $n$-hexane, methanol, pyridine, ethyl acetate, petroleum ether, and water. The color reaction was tested with anisaldehyde, anthrone, Barton solution, bromcresol green, dinitrophenylhydrazine, Dragendorff solution, 8-hydroxyquinoline- $\mathrm{NH}_{3}$, copper acetate, Legal solution, Molish solution, ninhydrin, rhodamine, and potassium permanganate.

Melting point was measured with a Micro Melting Point Apparatus (Yanako). Optical rotation was performed with an AA-5 spectrometer (Optical Activity Ltd.). Ultraviolet spectrum was recorded with a 150-20 spectrophotometer (Hitachi). Infrared spectrum was recorded with an A-100 spectrophotometer (Japan Spectrascopic Co., Ltd.). Secondary ionization mass measurement was supplied by Ueno Fine Chemical Industries, Ltd.

Antiviral activity of $46 \mathrm{NW}-04 \mathrm{~A}$ against salmonid viruses. - Antiviral activity of $46 \mathrm{NW}-04 \mathrm{~A}$ was tested against two RNA viruses-IHNV and IPNV - and the DNA virus OMV. Serial twofold dilutions of the substance were made in $1 \%$ DMSO in Hanks' BSS to give the concentrations of 100 , $50,25,12.5$, and $6 \mu \mathrm{g} / \mathrm{mL}$. These were compared for antiviral activity by plaque reduction.

Taxonomic study of Pseudomonas sp. $46 \mathrm{NW}$ 04. - Tests used to classify Pseudomonas sp. 46 NW-04 were those of Bergey's Manual of Systematic Bacteriology (Palleroni 1984) and Stanier 


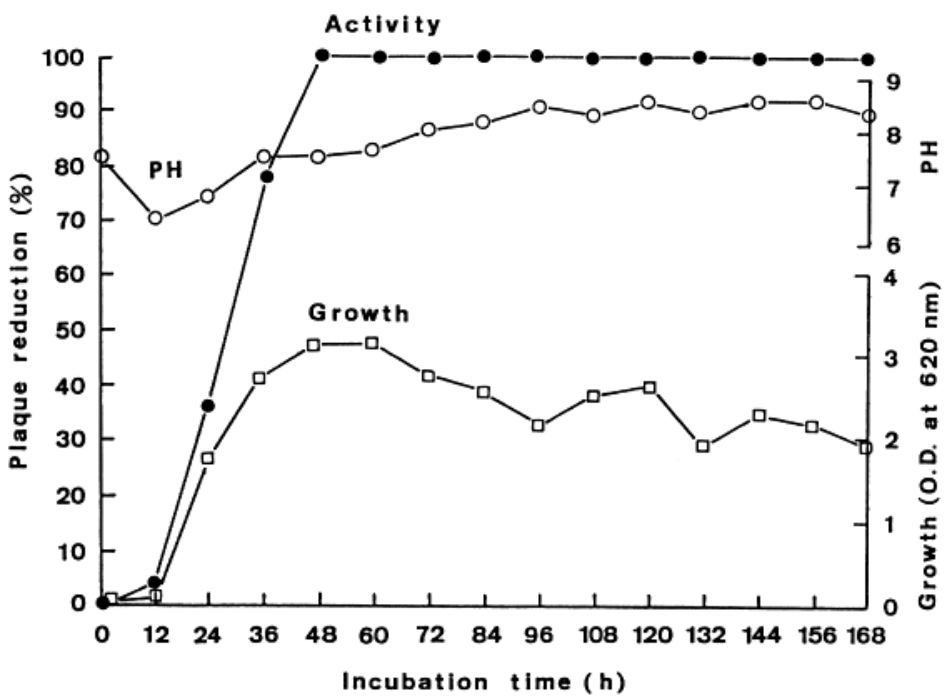

FIGURE 3.-Time course of growth and the production of anti-IHNV agent by Pseudomonas sp. 46NW-04 incubated at $25^{\circ} \mathrm{C}$; O.D. = optical density.

et al. (1966). The tests included seven reference strains of Pseudomonas: Pseudomonas fluorescens (National Collection of Marine Bacteria: NCMB 129), P. putida (NCMB 406), P. stutzeri (American Type Culture Collection: ATCC 17588), $P$. mendocina (ATCC 25411), P. pseudoalcaligenes (ATCC 17440), P. acidovorans (ATCC 15668), and P. saccharophila (Institute of Applied Microbiology, Tokyo University: IAM 1504). Freshwater agar (FWA) medium (Yoshimizu et al. 1976) was used as the basal medium for tests of gelatin, starch, Tween 80 , and poly- $\beta$-hydroxybutyrate (PHB) hydrolysis, levan formation, and denitrification. The test strains were grown in $5 \mathrm{~mL}$ of trypticase soy broth (TSB; Baltimore Biological Laboratory) at $25^{\circ} \mathrm{C}$ for $24 \mathrm{~h}$. One loopful of each culture was inoculated into each of the test media. Each test was read after incubation at $25^{\circ} \mathrm{C}$ for $5 \mathrm{~d}$. The percent of guanine and cytosine in the bacterial DNA (mol \% GC) was measured and averaged for three trials.

\section{Results}

\section{Production of $46 \mathrm{NW}-04 \mathrm{~A}$}

Production of the antiviral agent $46 \mathrm{NW}-04 \mathrm{~A}$ by Pseudomonas sp. 46NW-04 was first determined at temperatures from 10 to $33^{\circ} \mathrm{C}$. The bacterium grew well between 14 and $30^{\circ} \mathrm{C}$, and maximum growth was observed at $19^{\circ} \mathrm{C}$. Antiviral activity was highest in the culture incubated at $25-30^{\circ} \mathrm{C}$ (Figure 2). During the incubation period, the $\mathrm{pH}$ changed from 7.2 to about 7.8 , and this change did not affect the antiviral activity. Production of
TABLE 1.-Physicochemical properties of antiviral substance $46 \mathrm{NW}-04 \mathrm{~A}$ produced by Pseudomonas sp. 46NW-04.

\begin{tabular}{|c|c|}
\hline Characteristic & Description or value \\
\hline Appearance & White powder \\
\hline Melting point & $206-208^{\circ} \mathrm{C}$ \\
\hline $\begin{array}{l}\text { Optical rotation at } \\
25^{\circ} \mathrm{C}(2 \% \text { solu- } \\
\text { tion in methanol })\end{array}$ & -47.5 \\
\hline $\begin{array}{l}\text { Molecular weight } \\
\text { (by mass spec- } \\
\text { trometry) }\end{array}$ & 1,126 \\
\hline Elemental analysis & C, $54.68 \% ; \mathrm{H}, 8.49 \% ; \mathrm{N}, 10.0 \%$ \\
\hline $\begin{array}{l}\text { Wavelength (in nm) } \\
\text { at maximum ab- } \\
\text { sorption of ultra- } \\
\text { violet light (mo- } \\
\text { lecular extinction } \\
\text { coefficient) }\end{array}$ & $204(18,200)$ \\
\hline $\begin{array}{l}\text { Absorption bands } \\
\left(\mathrm{cm}^{-1}\right) \text { of infrared } \\
\text { light }\end{array}$ & $\begin{array}{l}3,300,2,950,2,920,2,850,1,730 \\
\quad 1,650,1,520,1,460,1,370,1,270 \\
1,060\end{array}$ \\
\hline Stability & Stable at pH 3-10 \\
\hline Solubility & $\begin{array}{l}\text { Soluble in methanol, ethanol, ethyl } \\
\text { acetate, acetone, benzene, chloro- } \\
\text { form, diethyl ether, dimethylsulfox- } \\
\text { ide, and pyridine. Insoluble in } \\
n \text {-hexane, petroleum ether, and } \\
\text { water. }\end{array}$ \\
\hline Color reaction & $\begin{array}{l}\text { Positive for anisaldehyde, bromcresol } \\
\text { green, dinitrophenylhydrazine, Drag- } \\
\text { endorff solution, and 8-hydroxyquin- } \\
\text { oline- } \mathrm{NH}_{3} \\
\text { Negative for potassium permanganate, } \\
\text { anthron, Barton solution, copper } \\
\text { acetate, Legal solution, Molish solu- } \\
\text { tion, ninhydrin, and rhodamine }\end{array}$ \\
\hline
\end{tabular}


TABLE 2.-Activity of antiviral substance $46 \mathrm{NW}-04 \mathrm{~A}$ against fish viruses.

\begin{tabular}{cccc}
\hline $\begin{array}{c}\text { Concen- } \\
\text { tration of } \\
46 \mathrm{NW}-04 \mathrm{~A}\end{array}$ & Antiviral activity (\% plaque reduction) against \\
\cline { 2 - 4 }$(\mu \mathrm{g} / \mathrm{mL})$ & OMV & IHNV & IPNV \\
\hline 50 & 100 & 100 & 0 \\
25 & 100 & 100 & 0 \\
12.5 & 100 & 94 & 0 \\
6 & 60 & 58 & 0 \\
3 & 25 & 37 & 0 \\
\hline
\end{tabular}

antiviral substance was tested during incubation at $25^{\circ} \mathrm{C}$. Bacterial growth reached a maximum at $48 \mathrm{~h}$ postincubation and antiviral activity increased during growth reaching a maximum after incubation for $48 \mathrm{~h}$ (Figure 3). Antiviral activity against IHNV remained high even after incubation for $168 \mathrm{~h}$.

\section{Purification of $46 \mathrm{NW}-04 \mathrm{~A}$ from the Culture Fluid}

In the preliminary experiments, antiviral activity was detected only in culture supernatants, but not in the cell pellets. After cultivation with agitation for $3 \mathrm{~d}$ at $25^{\circ} \mathrm{C}$, the culture had a pH of 8.6. When the antiviral substance was extracted with two volumes of ethyl acetate from $30 \mathrm{~L}$ of supernatant without acidification of the culture, about $3.7 \mathrm{~g}$ of a yellow-brown paste was produced. Following suspension in a mixture of chloroform and methanol, the material was subjected to column chromatography. Active fractions were pooled, concentrated, and further purified by thin-layer chromatography (TLC). Finally, $709 \mathrm{mg}$ of a white powder (46NW-04A) was obtained from an original volume of $30 \mathrm{~L}$ of culture. This substance was not detected on a TLC plate under ultraviolet light; therefore, purity was confirmed by anisaldehyde color reaction as a single spot on a TLC plate developed with various solvent sytems.

\section{Physicochemical Properties of $46 \mathrm{NW}-04 \mathrm{~A}$}

Physicochemical properties of $46 \mathrm{NW}-04 \mathrm{~A}$ are summarized in Table 1. This substance was readily soluble in acetone, methanol, ethanol, and

TABLE 3.-General characteristics of strains 46NW-04 and NCMB 129 of Pseudomonas fluorescens and species 1-5 of Pseudomonas (section I: P. fluorescens biovars I-V, P. aeruginosa, P. chlororaphis, P. aureofaciens, and $P$. putida biovars A and B) listed in Bergey's Manual of Systematic Bacteriology (Palleroni 1984). Abbreviations: $P$. $a .=$ Pseudomonas aeruginosa $; P$. ch.$=P$. chlororaphis $;$. au. $=P$. aureofaciens $;+=$ positive reaction; $-=$ negative reaction; $\mathrm{d}=$ reaction depends on bacterial strain; mol $\% \mathrm{GC}=$ the percent of guanine and cytosine in the bacterial DNA.

\begin{tabular}{|c|c|c|c|c|c|c|c|}
\hline \multirow[b]{4}{*}{ Characteristics } & \multirow{4}{*}{$\begin{array}{c}46 \mathrm{NW}- \\
04\end{array}$} & \multicolumn{6}{|c|}{ Reference species } \\
\hline & & \multicolumn{6}{|c|}{ P. fluorescens } \\
\hline & & \multirow{2}{*}{$\begin{array}{c}\text { NCMB } \\
129\end{array}$} & \multicolumn{5}{|c|}{ Biovar } \\
\hline & & & I & II & III & IV & V \\
\hline (1) Cell diameter, $\mu \mathrm{m}$ & 0.9 & & $0.7-0.8$ & $0.7-0.8$ & 0.8 & 0.7 & 0.8 \\
\hline (2) Cell length, $\mu \mathrm{m}$ & 2.2 & & $2.3-2.8$ & $2.0-2.8$ & $2.0-2.8$ & $2.0-2.5$ & $2.0-3.0$ \\
\hline (3) Number of flagella & $>1$ & & $>1$ & $>1$ & $>1$ & $>1$ & $>1$ \\
\hline (4) Pyocyanin production & - & - & - & - & - & - & - \\
\hline (5) Pyoverdin production & + & + & + & d & + & + & d \\
\hline (6) Chlororaphin production & - & - & - & - & - & - & - \\
\hline (7) Phenazine monocarboxylate production & - & - & - & - & - & - & - \\
\hline (8) Other pigments (not carotenoids) & - & - & - & - & - & d & - \\
\hline (9) Yellow-orange cellular pigments & - & - & - & - & - & - & - \\
\hline (10) Oxidase & + & + & + & + & + & + & + \\
\hline (11) Poly- $\beta$-hydroxybutyrate (PHB) accumulation & - & - & - & - & - & - & - \\
\hline (12) Levan formation from sucrose & + & + & + & + & - & + & - \\
\hline (13) Gelatin liquefaction & + & + & + & + & + & + & + \\
\hline (14) Starch hydrolysis & - & - & - & - & - & - & - \\
\hline (15) Autotrophic growth with $\mathrm{H}_{2}$ & & & - & - & - & - & - \\
\hline (16) Lecithinase (egg yolk) & + & + & + & \pm & + & + & d \\
\hline (17) Lipase (Tween 80 hydrolysis) & - & - & $\mathrm{d}$ & - & d & d & d \\
\hline (18) Extracellular PHB hydrolysis & - & - & - & - & - & - & - \\
\hline (19) Growth at $4^{\circ} \mathrm{C}$ & + & + & + & + & + & + & d \\
\hline (20) Growth at $41^{\circ} \mathrm{C}$ & - & - & - & - & - & - & - \\
\hline (21) Denitrification & - & - & - & + & + & + & - \\
\hline (22) Arginine dihydrolase & + & + & + & + & + & + & + \\
\hline (23) Catechol, ortho cleavage & & & + & + & + & + & + \\
\hline (24 Protocatechuate, ortho cleavage & + & + & + & + & + & + & + \\
\hline (25) $\mathrm{Mol} \% \mathrm{GC}$ & 59.9 & 60.7 & 60.5 & 61.3 & 60.6 & 59.4 & 60.5 \\
\hline
\end{tabular}


DMSO; weakly soluble in benzene, chloroform, ethyl acetate, and pyridine; very weakly soluble in diethyl ether; and insoluble in $n$-hexane, petroleum ether, and water. Color reactions of $46 \mathrm{NW}$ 04A were positive for anisaldehyde, bromcresol green, dinitrophenylhydrazine, Dragendorff solution, and 8-hydroxyquinoline- $\mathrm{NH}_{3}$, but negative for anthron, Barton solution, copper acetate, Legal solution, Molish solution (in this test, green color occurred), ninhydrin, potassium permanganate, and rhodamine.

Antiviral substance $46 \mathrm{NW}-04 \mathrm{~A}$ is a white powder with a melting point of $206-208^{\circ} \mathrm{C}$. A $2 \%$ solution of $46 \mathrm{NW}-04 \mathrm{~A}$ in methanol has an optical rotation of $-47.5^{\circ}$ at $25^{\circ} \mathrm{C}$. Its main constituents are carbon $(54.68 \%)$, hydrogen $(8.49 \%)$, and nitrogen $(10.0 \%)$. Its absorption of ultraviolet light in methanol showed a maximum at $204 \mathrm{~nm}$ with a molecular extinction coefficient at this wavelength of 18,200 . Molecular weight was determined to be 1,126 by mass spectrometry. The infrared absorption spectrum of $46 \mathrm{NW}-04 \mathrm{~A}$ showed bands characteristic of amine $\left(3,300 \mathrm{~cm}^{-1}\right)$, ketone $\left(1,730\right.$ and $\left.1,270 \mathrm{~cm}^{-1}\right)$, and carbonyl residues $\left(1,650 \mathrm{~cm}^{-1}\right)$, properties that suggest $46 \mathrm{NW}-04 \mathrm{~A}$ is a peptide.

TABLE 3.-Extended.

\begin{tabular}{|c|c|c|c|c|c|}
\hline \multirow{3}{*}{$\begin{array}{l}\text { Char- } \\
\text { acter- } \\
\text { istics }\end{array}$} & \multicolumn{5}{|c|}{ Reference species } \\
\hline & \multirow[b]{2}{*}{ P. $a$. } & \multirow[b]{2}{*}{ P. ch. } & \multirow[b]{2}{*}{ P. au. } & \multicolumn{2}{|c|}{ P. putida } \\
\hline & & & & $\begin{array}{c}\text { Biovar } \\
\text { A }\end{array}$ & $\begin{array}{c}\text { Biovar } \\
\text { B }\end{array}$ \\
\hline (1) & $0.5-0.7$ & $0.7-0.8$ & $0.7-0.8$ & $0.7-1.1$ & $0.7-1.1$ \\
\hline (2) & $1.5-3.0$ & $1.5-3.6$ & $1.9-2.8$ & $2.0-4.0$ & $2.0-4.0$ \\
\hline (3) & 1 & $>1$ & $>1$ & $>1$ & $>1$ \\
\hline (4) & + & - & - & - & - \\
\hline (5) & + & d & + & + & d \\
\hline (6) & - & + & - & - & - \\
\hline (7) & - & - & + & - & - \\
\hline (8) & + & - & - & - & - \\
\hline (9) & - & - & - & - & - \\
\hline (10) & + & + & + & + & + \\
\hline (11) & - & - & - & - & - \\
\hline (12) & - & + & + & - & - \\
\hline (13) & + & + & + & - & - \\
\hline (14) & - & - & - & - & - \\
\hline (15) & - & - & - & - & - \\
\hline (16) & - & + & d & - & - \\
\hline (17) & \pm & + & $\mathrm{d}$ & $\mathrm{d}$ & $\mathrm{d}$ \\
\hline (18) & - & - & - & - & - \\
\hline (19) & - & + & + & $\mathrm{d}$ & + \\
\hline (20) & + & - & - & - & - \\
\hline (21) & + & + & - & - & - \\
\hline (22) & + & + & + & + & + \\
\hline (23) & + & + & + & + & + \\
\hline (24) & + & + & + & + & + \\
\hline (25) & 67.2 & 63.5 & 63.6 & 62.5 & 60.7 \\
\hline
\end{tabular}

\section{Antiviral Activity against Three Fish Viruses}

Antiviral activity of 46NW-04A was examined with both DNA (OMV) and RNA (IHNV and IPNV) viruses. Plaque formation by OMV was completely inhibited by the addition of $12.5 \mu \mathrm{g}$ $46 \mathrm{NW}-04 \mathrm{~A} / \mathrm{mL}$ of this agent (Table 2). Even at 6 $\mu \mathrm{g} / \mathrm{mL}, 60 \%$ plaque reduction of the virus was observed, but little or no antiviral activity was noted at $3 \mu \mathrm{g} / \mathrm{mL}$. Similar results were obtained with IHNV; plaque reduction was $94 \%$ at $12.5 \mu \mathrm{g} /$ $\mathrm{mL}$ and $37 \%$ when the concentration of this substance decreased to $3 \mu \mathrm{g} / \mathrm{mL}$. No antiviral activity was observed for IPNV at concentrations as high as $50 \mu \mathrm{g} / \mathrm{mL}$. These results suggest that $46 \mathrm{NW}$ $04 \mathrm{~A}$ is only effective for enveloped viruses, regardless of their genome, because IHNV and OMV are enveloped viruses, whereas IPNV is not.

\section{Identification of Pseudomonas sp. 46NW-04}

We compared the characteristics of Pseudomonas sp. 46NW-04 to seven reference species of Pseudomonas. The accumulation of PHB, an important characteristic for the differentiation of Pseudomonas sp., was negative for Pseudomonas sp. 46NW-04, but not for P. pseudoalcaligenes and $P$. acidovarans. This suggests that Pseudomonas sp. $46 \mathrm{NW}-04$ belongs to section I of this genus according to Bergey's Manual of Systematic Bacteriology (Table 3 ). The strain could be grouped into any species or biovar of $P$. aeruginosa, $P$. fluorescens, $P$. chlororaphis, $P$. aureofaciens, or $P$. putida because it was positive for pyoverdin production and arginine dihydrolase; however, Pseudomonas sp. $46 \mathrm{NW}-04$ was positive for lecithinase and negative for production of pycyanine, chlororaphin, and phenazine monocarboxylate, so it is a strain of Pseudomonas fluorescens. In addition, examination of biovars $\mathrm{I}-\mathrm{V}$ of this species showed that Pseudomonas sp. 46NW-04 may be identified as Pseudomonas fluorescens biovar I, based on the properties of positive levan formation and negative denitrification (Table 4). The mol \% GC of DNA of the strain was 59.9, which confirmed that the Pseudomonas sp. that produces antiviral substances should be assigned to Pseudomonas fluorescens.

\section{Discussion}

We have reported that fish viruses were inactivated in freshwater, brackish water, and seawater samples, and that the inactivation was possibly caused by bacterial metabolites released in the water (Kamei et al. 1987a, 1988a; Yoshimizu et al. 1986). This possibility was investigated by screening about 1,500 bacterial isolates from water 
TABLE 4.-Characteristics of strains 46NW-04 and NCMB 129 of Pseudomonas fluorescens and species 2 ( $P$. fluorescens biovars I-V), 3 ( $P$. chlororaphis), and 4 (P. aureofaciens) of Pseudomonas (section I) listed in Bergey's Manual of Systematic Bacteriology (Palleroni 1984). The d indicates strain dependence.

\begin{tabular}{|c|c|c|c|c|c|c|c|c|c|}
\hline \multirow[b]{4}{*}{ Characteristics } & \multirow{4}{*}{$\begin{array}{l}\text { 46NW- } \\
04\end{array}$} & \multicolumn{8}{|c|}{ Reference species } \\
\hline & & \multicolumn{6}{|c|}{ P. fluorescens } & \multirow{3}{*}{$\begin{array}{c}P . \\
\text { chloro- } \\
\text { raphis }\end{array}$} & \multirow{3}{*}{$\begin{array}{c}P . \\
\text { aureo- } \\
\text { faciens }\end{array}$} \\
\hline & & \multirow{2}{*}{$\begin{array}{c}\text { NCMB } \\
129\end{array}$} & \multicolumn{5}{|c|}{ Biovar } & & \\
\hline & & & I & II & III & IV & V & & \\
\hline \multicolumn{2}{|l|}{$\begin{array}{l}\text { P. fluorescens biovars as designated } \\
\text { by Stanier et al. (1966) }\end{array}$} & & A & B & $\mathrm{C}$ & $\mathrm{F}$ & G & $\mathrm{D}$ & $\mathrm{E}$ \\
\hline \multicolumn{10}{|l|}{ Nonfluorescent pigments } \\
\hline Green (chlororaphin) & - & - & - & - & - & - & - & + & - \\
\hline Orange (phenazine-1-carboxylate) & - & - & - & - & - & - & - & - & + \\
\hline Blue, nondiffusible & - & - & - & - & - & + & - & - & - \\
\hline Levan formation from sucrose & + & + & + & + & - & + & - & + & + \\
\hline Denitrification & - & - & - & + & + & + & - & + & d \\
\hline \multicolumn{10}{|l|}{ Carbon sources used for growth: } \\
\hline L-Arabinose & + & + & + & + & $\mathrm{d}$ & + & $\mathrm{d}$ & - & + \\
\hline Sucrose & + & + & + & + & - & + & d & + & d \\
\hline Saccharate & - & - & + & + & d & + & d & + & + \\
\hline Propionate & + & + & + & + & d & + & + & + & + \\
\hline Butyrate & + & + & - & d & $\mathrm{d}$ & + & d & + & + \\
\hline Sorbitol & + & + & + & + & d & + & d & - & - \\
\hline Adonitol & + & + & + & - & d & - & d & - & - \\
\hline Propylene glycol & + & + & - & + & d & - & d & - & - \\
\hline Ethanol & - & - & - & + & d & - & $\mathrm{d}$ & $\mathrm{d}$ & - \\
\hline
\end{tabular}

and sediments by the plaque-reduction method (Kamei et al. 1987b, 1988b).

In this study, purification and testing of the antiviral substance from the culture supernatant of Pseudomonas sp. 46NW-04 was made by extraction with ethyl acetate, column chromatography, and TLC on silica gel. In the first step of the purification, a $50-\mu \mathrm{g} / \mathrm{mL}$ concentration of crude extract from the ethyl acetate layer completely inhibited plaque formation of IHNV (approximately 150 PFU) in CHSE-214 cells. However, antiviral activity was not detected in the bacterial cell pellet treated with methanol. The purified antiviral substance, 46NW-04A, showed potent antiviral activity against IHNV and OMV; it caused $100 \%$ plaque reduction at $25 \mu \mathrm{g} / \mathrm{mL}$ and still maintained activity at $12.5 \mu \mathrm{g} / \mathrm{mL}$. From $30 \mathrm{~L}$ of culture broth, $709 \mathrm{mg}$ of the purified substance was recovered, which corresponded to $23 \mu \mathrm{g} / \mathrm{mL}$ in the original culture solution. Our previous study showed that a $10 \%$ culture filtrate of Pseudomonas sp. (although the strain was different from the strain used in this study) caused considerable decrease of IHNV titer during a 3-d incubation period, and the viral inactivation was dependent on duration of exposure to the culture filtrate. We further demonstrated that a significant loss of viral infectivity (approximately 99\%) occurred within $3 \mathrm{~d}$ in pure bacterial cultures in $50 \%$ artificial seawater when washed cultures were used instead of the culture filtrate (Kamei et al. 1987a).

Several investigators have reported that the lack of viral survival in natural water is caused by microorganisms or extracellular compounds released from microorganisms (Toranzo et al. 1982, 1983; Ward et al. 1986). However, there have been no reports on antiviral substances actually isolated and characterized from microorganisms indigenous to aquatic environments. Several investigators have suggested that the causative agent of viral inactivation was proteolytic bacterial enzymes (Toranzo et al. 1982, 1983; Ward et al. 1986; Knowlton and Ward 1987), but few compounds with antiviral action have been isolated from microorganisms in aquatic environments. Most reports are limited to antibiotics active against bacteria or fungi (Rosenfeld and Zobell 1947; Grein and Meyers 1958; Burkholder et al. 1966; Doggett 1968; Ballester et al. 1977; Wratten et al. 1977; Lemos et al. 1985). Most bacteria that produce antiviral substances are actinomycetes isolated from marine mud (Okazaki and Okami 1972; Okazaki et al. 1975; Okami et al. 1976). Pseudomonas and Vibrio species have been reported to produce proteolytic enzymes (Toranzo et al. 1982, 1983). However, because of limited 
information about antibiotic-producing microorganisms in water, the ecological role of these microbes in the environment is still unknown.

The production of antiviral substance by $\mathrm{Pseu}$ domonas sp. 46NW-04 was influenced by incubation temperature. The antiviral activity was highest when the bacterium was grown at temperatures between 21 and $30^{\circ} \mathrm{C}$, although growth of the bacterium was observed between 14 and $19^{\circ} \mathrm{C}$. Neither antiviral activity nor bacterial growth was observed at temperatures higher than $30^{\circ} \mathrm{C}$, and the production of antiviral substance was greater at temperatures higher than the optimal growth temperature.

Studies of the time course of production showed that the amount of antiviral substance reached a maximum by $48 \mathrm{~h}$ when bacterial cultures were incubated at $25^{\circ} \mathrm{C}$ and agitated. Activity of the antiviral substance remained high for $168 \mathrm{~h}$. This indicated that the antiviral substance was not metabolized further and can be regarded as a stable substance. We believe this is the first report characterizing an antiviral substance from a Pseudomonas sp. isolated from an aquatic environment. This finding suggests the possibility that the antiviral activity observed in aquatic ecosystems may be due to the production of low-molecular-weight substances. The antiviral substance $46 \mathrm{NW}-04 \mathrm{~A}$ described in this report was different from the proteolytic enzymes described by Ward et al. (1986) and Knowlton and Ward (1987) because 46NW$04 \mathrm{~A}$ has a molecular weight of 1,126 . Negative ninhydrin reaction suggested that $46 \mathrm{NW}-04 \mathrm{~A}$ was a peptide blocked in its $N$-terminal residues.

Some bacterial enzymes may act synergistically by disrupting the viral structural integrity, but the mechanism is not known in detail. Preliminary experiments suggest that the antiviral substance 46NW-04A prevents adsorption of virus particles on host cells by changing the virus morphology or by coating the virus surface. Antiviral effect was found even if the substance was washed from infected cells, and the reactivity was particularly strong against enveloped viruses. Studies of the action of this antiviral substance on the viral structure could serve as a basis for elucidation of the mechanism of attachment and penetration of these fish viruses into host cells.

\section{Acknowledgments}

We express our sincere thanks to R. P. Hedrick, University of California-Davis, for his critical review of this paper and valuable suggestions. This research was supported in part by the Research
Fund of the Japan Fisheries Resource Conservation Association; a grant from the Research Council, Ministry of Agriculture, Forestry, and Fisheries, Japan, for original and creative research projects on biotechnology; and research grants 62790252 and 63470120 from the Ministry of Education, Science, and Culture of Japan.

\section{References}

Ballester, M., J. M. Ballester, and J. P. Belaich. 1977. Isolation and characterization of a high molecular weight antibiotic produced by a marine bacterium. Microbial Ecology 3:289-303.

Burkholder, P. R., R. M. Pfister, and F. H. Leitz. 1966. Production of a pyrrole antibiotic by a marine bacterium. Applied Microbiology 14:649-653.

Cliver, D. O., and J. E. Herrmann. 1972. Proteolytic and microbial inactivation of enteroviruses. Water Research 6:797-805.

Doggett, R. G. 1968. New anti-Pseudomonas agent isolated from a marine Vibrio. Journal of Bacteriology 95:1972-1973.

Fryer, J. L., A. Yusha, and K. S. Pilcher. 1965. The in vitro cultivation of tissue and cells of Pacific salmon and steelhead trout. Annals of the New York Academy of Sciences 126:566-586.

Fujioka, R. S., P. C. Loh, and L. S. Lau. 1980. Survival of human enteroviruses in the Hawaiian ocean environment: evidence for virus-inactivating microorganisms. Applied and Environmental Microbiology 39:1105-1110.

Grein, A., and P. S. Meyers. 1958. Growth characteristics and antibiotic production of actinomycetes isolated from littoral sediments and materials suspended in sea water. Journal of Bacteriology 76: 457-463.

Kamei, Y., M. Yoshimizu, Y. Ezura, and T. Kimura. 1987a. Effects of estuarine and marine waters on the infectivities of infectious hematopoietic necrosis virus (IHNV) and infectious pancreatic necrosis virus (IPNV). Bulletin of the Faculty of Fisheries Hokkaido University 38:271-285.

Kamei, Y., M. Yoshimizu, Y. Ezura, and T. Kimura. $1987 \mathrm{~b}$. Screening of bacteria with antiviral activity against infectious hematopoietic necrosis virus (IHNV) from estuarine and marine environments. Bulletin of the Japanese Society of Scientific Fisheries 53:2179-2185.

Kamei, Y., M. Yoshimizu, and T. Kimura. 1987c. Plaque assay of Oncorhynchus masou virus (OMV). Fish Pathology 22:147-152.

Kamei, Y., M. Yoshimizu, Y. Ezura, and T. Kimura. 1988a. Effects of environmental water on the infectivities of infectious hematopoietic necrosis virus (IHNV) and infectious pancreatic necrosis virus (IPNV). Journal of Applied Ichthyology 4:37-47.

Kamei, Y., M. Yoshimizu, Y. Ezura, and T. Kimura. 1988 b. Screening of bacteria with antiviral activity from fresh water salmonid hatcheries. Microbiology and Immunology 32:67-73. 
Knowlton, D. R., and R. L. Ward. 1987. Characterization of virucidal agents in activated sludge. Applied and Environmental Microbiology 53:621-626.

Lemos, M. L., A. E. Toranzo, and J. L. Barja. 1985. Antibiotic activity of epiphytic bacteria isolated from intertidal seaweeds. Microbial Ecology 11:149-163.

Magnusson, S., K. Gundersen, A. Brandberg, and E. Lycke. 1967. Marine bacteria and their possible relation to the virus inactivation capacity of sea water. Acta Pathologica et Microbiologica Scandinavica 71:274-280.

Okazaki, T., T. Kitahara, and Y. Okami. 1975. Studies on marine microorganisms. IV. A new antibiotic SS-228 Y produced by Chainia isolated from shallow sea mud. Juornal of Antibiotics (Tokyo) 28: $176-184$.

Okazaki, T., and Y. Okami. 1972. Studies on marine microorganisms. II. Actinomycetes in Sagami Bay and their antibiotic substances. Journal of Antibiotics (Tokyo) 25:461-466.

Okami, Y., T. Okazaki, T. Kitahara, and H. Umezawa. 1976. Studies on marine microorganisms. V. A new antibiotic, aplasmomycin, produced by a streptomycete isolated from shallow sea mud. Journal of Antibiotics (Tokyo) 29:1019-1025.

Palleroni, N. J. 1984. Genus I. Pseudomonas. Pages 141-199 in N. R. Krieg and J. G. Holt, editors. Bergey's manual of systematic bacteriology, volume 1. Williams \& Wilkins, Baltimore, Maryland.

Rosenfeld, W. D., and C. E. ZoBell. 1947. Antibiotic production by marine microorganisms. Journal of Bacteriology 54:393-398.

Stahl, E., and U. Kaltenbach. 1961. Dünnschichtchromatographie. VI. Mitteilung. Spurenanalyse von Zuckergemischen auf Kieselgur Ge-schichten. Journal of Chromatography 5:351-355.

Stanier, R. Y., N. J. Palleroni, and M. Doudoroff. 1966.
The aerobic pseudomonads: a taxonomic study. Journal of General Microbiology 43:159-271.

Toranzo, A. E., J. L. Barja, and F. M. Hetrick. 1982. Antiviral activity of antibiotic-producing marine bacteria. Canadian Journal of Microbiology 28:231238.

Toranzo, A. E., J. L. Barja, and F. M. Hetrick. 1983. Mechanism of poliovirus inactivation by cell-free filtrates of marine bacteria. Canadian Journal of Microbiology 29:1481-1486.

Ward, R. L. 1982. Evidence that microorganisms cause inactivation of viruses in activated sludge. Applied and Environmental Microbiology 43:1221-1224.

Ward, R. L., D. S. Knowlton, and P. E. Winston. 1986. Mechanism of inactivation of enteric viruses in fresh water. Applied and Environmental Microbiology 52: 450-459.

Wolf, K., and M. C. Quimby 1962. Established eurythermic line of fish cells in vitro. Science (Washington, D.C.) 135:1065-1066.

Wratten, S. J., M. S. Wolfe, R. J. Andersen, and D. J. Faulkner. 1977. Antibiotic metabolites from a marine pseudomonad. Antimicrobial Agents and Chemotherapy 11:411-414.

Yoshimizu, M., T. Kimura, and M. Sakai. 1976. Studies on the intestinal microflora of salmonids $-I$. The intestinal microflora of fish reared in fresh water and sea water. Bulletin vi the Japanese Society of Scientific Fisheries 42:91-99.

Yoshimizu, M., H. Takizawa, Y. Kamei, and T. Kimura. 1986. Interaction between fish pathogenic viruses and microorganisms in fish rearing water: survival and inactivation of infectious pancreatic necrosis virus, infectious hematopoietic necrosis virus and Oncorhynchus masou virus in rearing water. Fish Pathology 21:223-231. 